\title{
Synthesis and fungicidal activity of some sulphide derivatives of $\mathrm{O}$-phenyl-N-substituted phenylcarbamates
}

\author{
F. E. Adelowo ${ }^{1 *}$, I. A. O. Ojo ${ }^{2}$, O. S. Amuda ${ }^{1}$ \\ ${ }^{1}$ Department of Pure and Applied Chemistry, Ladoke Akintola University of Technology, Ogbomoso, Nigeria; \\ ${ }^{2}$ Department of Chemistry, Obafemi Awolowo University, Ile-Ife, Nigeria. \\ Email: funmiadelowo2000@yahoo.com
}

Received 5 August 2011; revised 13 September 2011; accepted 24 September 2011.

\begin{abstract}
Monosulphides of O-phenyl-N-substituted phenylcarbamates were prepared by the reaction between $\mathrm{O}$ phenyl-N-substituted phenylcarbamates and sulphur dichloride while the corresponding disulphides were prepared by the reaction between $\mathrm{O}$-phenyl- $\mathrm{N}$ substituted phenylcarbamates and sulphur monochloride. The synthesized compounds were characterized by elemental analysis, thin layer chromatography (TLC), Fourier-transform infrared, ${ }^{1} \mathrm{H}$ and ${ }^{13} \mathrm{C}$ nuclear magnetic resonance spectroscopic techniques. In vitro fungicidal assay of these sulphides against Fusarium oxysporum, Aspergillus niger, Aspergillus flavus and Rhizopus stolonifer showed that they were more fungicidal than their parent carbamates. The synthesized sulphides were more active towards Aspergillus niger and Aspergillus flavus. There was little or no variations in the fungicidal activities of the synthesized monosulphides and disulphides of O-phenyl-N-substituted phenyl carbamates.
\end{abstract}

Keywords: Fungicidal Activity; Sulphide Derivatives; Synthesis

\section{INTRODUCTION}

Variations in the structure of sulphur-containing compounds have led to increased fungicidal activity $[1,2]$. Fungicides are chemicals that combat the attack of various fungi species. Organosulphur compounds are economically important fungicides that play a significant role in the production of agricultural crops and in the preservation of industrial products [3].

Dithiocarbamates and their derivatives were one of the early groups of organic sulphur fungicides. They were discovered by Tisdale and Williams in 1934 [4]. The properties of the dithiocarbamates could be changed by replacement of the sulphur hydrogen with metals or other substituents [5] Extending the alkyl chain could lead to loss of activity while optimum activity could be achieved with two methyl groups on the nitrogen of the dithiocarbamates [2].

Sulphur derivatives of carbonates were among the recently introduced fungicides. They were prepared from the reaction between carbon disulphide, sulphur and caustic soda [6]. Tetrathiocarbonate and thiozolidinedione gave a broad spectrum control of nematodes, nutrifying bacteria and a wide range of soil fungi $[7,8]$.

The stability of the metal-chelate [9] formed between the heavy metals present in fungi cells and the fungicide sulphur determines the fungicidal activity of these organosulphur compounds. Formation of such metal-chelates would increase the hydrophobic property of metal ions and this would enable them to pass through lipoid layers of cellular membranes to the fungus cells, thereby leading to their poisoning $[10,11]$.

A wide variety of functional groups have been introduced into the structure of carbamates. These include sulfenyl, thiono, thiocarbonyl, acyl, sulfinyl, sulfonyl phosphinothioyl and diatazole groups [12-18]. The most widely used functional group for the derivatization of carbamates is the sulfenyl group [15,16,19-22]. Several types of $\mathrm{N}$-sulfenylated carbamates have shown higher fungicidal activity than their corresponding parent compounds [1].

This report is concerned with the sulfenylation of some O-phenyl-N-substituted phenylcarbamates and the potential use of the derivatized products as fungicides. This is in line with our research efforts on the synthesis, structure-activity relationships of organosulphur compounds.

\section{MATERIALS AND METHODS}

\subsection{Reagents and Solvents}

Solid reagents were re-crystallized while solvents were re-distilled. Toluene and di-ethyl ether were dried over sodium wire. Sulphur monochloride was re-distilled over sulphur and collected at $138^{\circ} \mathrm{C}-139^{\circ} \mathrm{C}$. Similarly sul- 
phur dichloride was purified by distillation and the fraction collected at $58^{\circ} \mathrm{C}-59^{\circ} \mathrm{C}$.

\subsection{Synthesis of Parent Compounds}

O-phenyl-N-substituted phenylcarbamates were prepared by the reaction between phenyl chloroformate and substituted aniline in the presence of pyridine which was used for trapping the generated $\mathrm{HCl}$. The general procedure for the synthesis of O-phenyl-N-substituted phenylcarbamates was as reported previously [23].

\subsubsection{O-Phenyl-N-(3-nitrophenyl) carbamate}

Phenyl chloroformate $\left(7.8 \mathrm{~g}, 6.3 \mathrm{~cm}^{3}, 0.05 \mathrm{~mol}\right)$ and 3-nitroaniline (6.9 g, $0.05 \mathrm{~mol}$ ) gave O-phenyl-N-(3nitrophenyl) carbamate $(9.0 \mathrm{~g}, 70 \%)$ as a bright yellow crystalline solid on re-crystallization from methanol; (Found: C, 61.10; N, 10.95. Calc. for $\mathrm{C}_{13} \mathrm{H}_{10} \mathrm{~N}_{2} \mathrm{O}_{4}$ : C, 60.46; N, $10.85 \%$ ); m.p. $110^{\circ} \mathrm{C}-112^{\circ} \mathrm{C}$. The TLC (ethanol/DMSO, 3:1) gave a single spot, $\mathrm{R}_{\mathrm{f}}=0.82 ;{ }^{1} \mathrm{H}$ $\left(\mathrm{C}_{3} \mathrm{D}_{6} \mathrm{O}\right)$ : 7.2 - 8.8 (Ar-H, m, 9H), 9.8(N-H, b.s., $\left.1 \mathrm{H}\right)$.

\subsubsection{O-Phenyl-N-(4-nitrophenyl) Carbamate}

Phenyl chloroformate $\left(7.8 \mathrm{~g}, 6.3 \mathrm{~cm}^{3}, 0.05 \mathrm{~mol}\right)$ and 4-nitroanaline (6.9 g, $0.05 \mathrm{~mol}$ ) gave O-phenyl-N-(4-nitrophenyl) carbamate (10.6 g, 82\%) as a yellow crystalline solid on re-crystallization from methanol; (Found: $\mathrm{C}$, 60.59; N, 9.98. Calc. for $\mathrm{C}_{13} \mathrm{H}_{10} \mathrm{~N}_{2} \mathrm{O}_{4}$ : C, 60.46; N, $10.85 \%$ ); m.p. $118^{\circ} \mathrm{C}-119^{\circ} \mathrm{C}$. The TLC (ethanol/DMSO, $3: 1$ ) gave a single spot, $\mathrm{R}_{\mathrm{f}}=0.84 ;{ }^{1} \mathrm{H}\left(\mathrm{C}_{3} \mathrm{D}_{6} \mathrm{O}\right): 7.1$ - 8.9 (Ar-H, m, 9H), 9.8(N-H, b.s., $1 \mathrm{H}$ )

\subsubsection{O-Phenyl-N-(4-chlorophenyl) Carbamate}

Phenyl chloroformate $\left(7.8 \mathrm{~g}, 6.3 \mathrm{~cm}^{3}, 0.05 \mathrm{~mol}\right)$ and 4-chloroaniline $(6.4 \mathrm{~g}, 0.05 \mathrm{~mol})$ gave O-phenyl-N(4chlorophenyl) carbamate $(9.7 \mathrm{~g}, 78 \%)$ as a dark brown crystalline solid on re-crystallization from methanol;
(Found: C, 63.10; N, 5.78. Calc. for $\mathrm{C}_{13} \mathrm{H}_{10} \mathrm{ClNO}_{2}$ : C, 63.03; N, 5.66\%); m.p. $126{ }^{\circ} \mathrm{C}-127^{\circ} \mathrm{C}$. The TLC (ethanol/DMSO, 3:1) gave a single spot, $\mathrm{R}_{\mathrm{f}}=0.76 ;{ }^{1} \mathrm{H}$ $\left(\mathrm{C}_{3} \mathrm{D}_{6} \mathrm{O}\right)$ : 7.1 - 8.1 (Ar-H, m, 9H), 9.4 (N-H, b.s., $\left.1 \mathrm{H}\right)$.

The infrared spectra of the synthesized carbamates showed strong carbonyl stretching bands between 1700 $\mathrm{cm}^{-1}$ and $1705 \mathrm{~cm}^{-1}$ while the secondary amide bands appeared between $3300 \mathrm{~cm}^{-1}$ and $3350 \mathrm{~cm}^{-1}$ for $\mathrm{N}-\mathrm{H}$ stretching.

\subsection{Synthesis of Symmetrical Bis-[N-phenoxycarbonyl-N-(3-nitrophenyl)] Monosulphide}

O-phenyl-N-(3-nitrophenyl) carbamate (1.29 g, 0.005 mol) was dissolved in carbon tetrachloride $\left(20 \mathrm{~cm}^{3}\right)$. To the brown solution was added excess pyridine $\left(10 \mathrm{~cm}^{3}\right)$. Chilled sulphur dichloride, $\mathrm{SCl}_{2}\left(0.52 \mathrm{~g}, 0.4 \mathrm{~cm}^{3}, 0.005\right.$ mol) dissolved in carbon tetrachloride $\left(10 \mathrm{~cm}^{3}\right)$ was added dropwisely from a dropping funnel. The whole reaction mixture was set up in a $250 \mathrm{~cm}^{3}$ three-necked reaction flask fitted with a reflux condenser, a dropping funnel and a magnetic stirrer. The reaction mixture was stirred for 1 hour at $20^{\circ} \mathrm{C}$ in a fume cupboard. White fumes of hydrogen chloride, which disappeared with time was produced (Figure 1). An equimolar quantity of O-phenyl-N-(3-nitrophenyl) carbamate (1.29 g, 0.005 mol) dissolved in carbon tetrachloride $\left(20 \mathrm{~cm}^{3}\right)$ was added to the reaction mixture through the dropping funnel. Further evolution of white fumes was observed. The reaction mixture was stirred for another 1 hour and finally left to stir overnight at room temperature The reaction mixture was washed with $10 \%$ hydrochloric acid $\left(100 \mathrm{~cm}^{3}\right)$ solution in a separatory funnel. The organic layer was separated and washed with distilled water o<smiles>CCCCOC(=O)Nc1cccc([N+](=O)[O-])c1</smiles>

Figure 1. Synthesis of bis-[N-phenoxycarbonyl-N-(3-nitrophenyl)] monosulphide. 
$\left(3 \times 100 \mathrm{~cm}^{3}\right)$. The brown organic layer was separated from the aqueous layer, dried with anhydrous sodium sulphate and filtered under suction. Volatile solvents were removed by means of a rotary evaporator to leave an oily residue which was solidified on cooling. The crude product was re-crystallized from methanol to give the desired product, bis-[N-phenoxycarbonyl-N-(3-nitrophenyl)] monosulphide, (I) (2.16 g, 79\%) as brown crystals of m.p. $134^{\circ} \mathrm{C}-135^{\circ} \mathrm{C}$; (Found: C, 56.09; N, 10.35; S, 6.68. Calc. for $\mathrm{C}_{26} \mathrm{H}_{18} \mathrm{~N}_{4} \mathrm{O}_{8} \mathrm{~S}$ : C, 57.13; N, 10.25; S, $5.87 \%$ ); TLC (ethanol/DMSO, 3:1) gave a single spot with $\mathrm{R}_{\mathrm{f}}=0.65 ;{ }^{1} \mathrm{H}$ (DMSO): 7.8 - 8.5 (Ar-H, m, 18H). The infrared spectrum of the synthesized compound showed a strong carbonyl absorption at $1720 \mathrm{~cm}^{-1}$ and absence of amide band of N-H stretching.

The above procedure was used for the synthesis of other symmetrical monosulphides.

\subsubsection{Bis-[N-phenoxycarbonyl-N-(4-nitrophenyl] Monosulphide}

O-phenyl-N-(4-nitrophenyl) carbamate [2 × $(1.30 \mathrm{~g}$, $0.005 \mathrm{~mol})]$ and sulphur dichloride $\left(0.52 \mathrm{~g}, 0.4 \mathrm{~cm}^{3}\right.$, $0.005 \mathrm{~mol}$ ) gave the product bis-[N-phenoxycarbonyl-N(4-nitrophenyl)] monosulphide (1.78 g, 65\%), as brown crystals of m.p. $140^{\circ} \mathrm{C}-141^{\circ} \mathrm{C}$; (Found: C, 57.10; N, 10.02; S, 6.01. Calc. for $\mathrm{C}_{26} \mathrm{H}_{18} \mathrm{~N}_{4} \mathrm{O}_{8} \mathrm{~S}$ : C, 57.13; N, 10.25; S, 5.87\%). TLC (ethanol/DMSO, 3:1) gave a single spot with $\mathrm{R}_{\mathrm{f}}=0.64 ;{ }^{1} \mathrm{H}(\mathrm{DMSO}): 7.5-8.2(\mathrm{Ar}-\mathrm{H}, \mathrm{m}$, $18 \mathrm{H})$.

\subsubsection{Bis-[-N-phenoxycarbonyl-N-(4-chlorophenyl)] Monosulphide \\ O-phenyl-N-(4-chlorophenyl) carbamate [2 × (1.24 g,}

$0.005 \mathrm{~mol})]$ and sulphur dichloride $\left(0.52 \mathrm{~g}, 0.4 \mathrm{~cm}^{3}\right.$, $0.005 \mathrm{~mol}$ ) gave the product, bis-[N-phenoxycarbonyl$\mathrm{N}$-(4-chlorophenyl)] monosulphide $(1.84 \mathrm{~g}, 70 \%)$ as a brown crystalline solid on re-crystallization from methanol; (Found: C, 59.29; N, 5.51; S, 6.71. Calc. for $\mathrm{C}_{26} \mathrm{H}_{18} \mathrm{Cl}_{2} \mathrm{~N}_{2} \mathrm{~S}$ : C, 59.43; N, 5.33; S, 6.10\%); m.p. $78^{\circ} \mathrm{C}$ $79^{\circ} \mathrm{C}$. TLC (ethanol/DMSO, 3:1) gave a single spot with $\mathrm{R}_{\mathrm{f}}=0.65 ;{ }^{1} \mathrm{H}$ (DMSO): 7.4 - 8.9 (Ar-H, m, 18H).

\subsection{A General Procedure for the Synthesis of Symmetrical Disulphides}

\subsubsection{Synthesis of Bis-[N-phenoxycarbonyl- N-(3-nitrophenyl)] Disulphide}

To a solution of O-phenyl-N-(3-nitrophenyl) carbamate (1.29 g, $0.005 \mathrm{~mol})$ dissolved in carbon tetrachloride (20 $\left.\mathrm{cm}^{3}\right)$, was added excess triethylamine, $\mathrm{Et}_{3} \mathrm{~N}\left(10 \mathrm{~cm}^{3}\right)$. Chilled sulphur monochloride, $\mathrm{S}_{2} \mathrm{Cl}_{2}\left(0.68 \mathrm{~g}, 0.4 \mathrm{~cm}^{3}, 5\right.$ mmol), dissolved in carbon tetrachloride $\left(10 \mathrm{~cm}^{3}\right)$ was added dropwisely from a dropping funnel, whilst the reaction mixture was maintained below $10^{\circ} \mathrm{C}$ by the addition of ice to the water bath in which the reaction vessel stood. White fumes which disappeared with time were produced. The reaction mixture was kept stirring for another 30 minutes after the addition of sulphur monochloride was completed. An equimolar quantity of O-phenyl-N-(3-nitrophenyl) carbamate (1.29 g, 0.005 $\mathrm{mol})$, dissolved in carbon tetrachloride $\left(20 \mathrm{~cm}^{3}\right)$ was added dropwisely to the reaction mixture. Further evolution of white fumes as observed. The reaction mixture was allowed to stir at a temperature below $10^{\circ} \mathrm{C}$ for an additional 30 minutes and finally left to stir overnight at room temperature (Figure 2). The solid, triethylamine

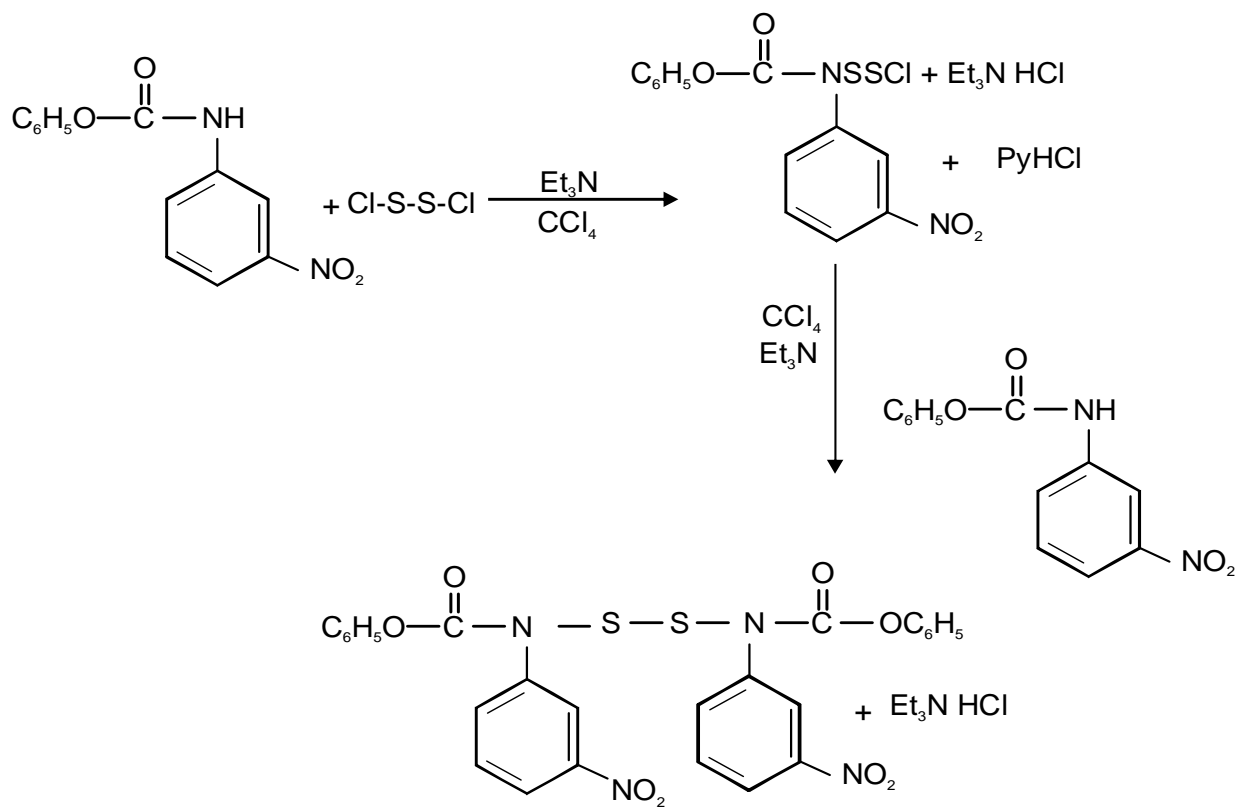

Figure 2. Synthesis of bis-[N-phenoxycarbonyl-N-(3-nitrophenyl)] disulphide. 
hydrochloride was removed by filtration. The filtrate was washed with $10 \%$ hydrochloric acid $\left(100 \mathrm{~cm}^{3}\right)$ solution in a separatory funnel. The organic layer was washed with distilled water $\left(3 \times 10^{2} \mathrm{~cm}^{3}\right)$, dried with anhydrous sodium sulphate and filtered. Volatile solvents were removed from the filtrate by means of a rotary evaporator to leave an oil, which was solidified on standing. The crude product was re-crystallized from methanol to give the desired product, bis-[N-phenoxycarbonyl-N-(3-nitrophenyl)] disulphide (II) (1.9 g, 65\%), as a brown crystalline solid, m.p. $108^{\circ} \mathrm{C}-109^{\circ} \mathrm{C}$; (Found: C, 54.01; N, 9.57; S, 10.30. Calc. for $\mathrm{C}_{26} \mathrm{H}_{18} \mathrm{~N}_{4} \mathrm{O}_{8} \mathrm{~S}_{2}$ : C, 53.97; N, 9.68; S, 11.08\%). TLC (ethanol/DMSO 3:1) gave a single spot, $\mathrm{R}_{\mathrm{f}}=0.51 ;{ }^{1} \mathrm{H}$ (DMSO): $7.2-7.8$ $(\mathrm{Ar}-\mathrm{H}, \mathrm{m}, 18 \mathrm{H})$. The infrared spectrum of the synthesized compound showed a strong carbonyl absorption at $1725 \mathrm{~cm}^{-1}$ and absence of amide band of N-H stretching. The above procedure was used for the synthesis of other symmetrical disulphides.

\subsubsection{Bis-[N-phenoxycarbonyl-N-(4-nitrophenyl)] Disulphide}

O-phenyl-N(4-nitrophenyl) carbamate [2 × (1.30 g, 0.005 $\mathrm{mol})]$ and sulphur monochloride $\left(0.68 \mathrm{~g}, 0.4 \mathrm{~cm}^{3}, 0.005\right.$ mol.) gave the product, bis-[N-phenoxycarbonyl-N-(4nitrophenyl)] disulphide (2.26 g, 78\%) as a brown crystalline solid, m.p. $150^{\circ} \mathrm{C}-151^{\circ} \mathrm{C}$; (Found: C, 53.88; N, 9.59; S, 10.54. Calc. for $\mathrm{C}_{26} \mathrm{H}_{18} \mathrm{~N}_{4} \mathrm{O}_{8} \mathrm{~S}_{2}$ : C, 53.97; N, 9.68; S, 11.08\%). TLC (ethanol/DMSO 3:1) gave a single spot, $\mathrm{R}_{\mathrm{f}}$ $=0.50 .{ }^{1} \mathrm{H}$ (DMSO): 7.5 - 7.9 (Ar-H, m, 18H).

\subsubsection{Bis-[N-phenoxycarbonyl-N-(4-chlorophenyl)] Disulphide}

O-phenyl-N-(4-chlorophenyl carbamate [2 × (1.24 g, 0.005 mol)] and sulphur monochloride $\left(0.68 \mathrm{~g}, 0.4 \mathrm{~cm}^{3}, 0.005\right.$ mol.) gave the product, bis-[N-phenoxycarbonyl-N-(4chlorophenyl)] disulphide as a brown crystalline solid (2.26 g, 81\%), m.p. $118^{\circ} \mathrm{C}-119^{\circ} \mathrm{C}$; (Found: C, 56.33; N, 5.14; S, 12.97. Calc. for $\mathrm{C}_{26} \mathrm{H}_{18} \mathrm{Cl}_{2} \mathrm{~N}_{2} \mathrm{O}_{4} \mathrm{~S}_{2}$ : C, 56.01; N, 5.03; S, 11.49\%). TLC (ethanol/DMSO 3:1) gave a single spot, $\mathrm{R}_{\mathrm{f}}=0.53 .{ }^{1} \mathrm{H}$ (DMSO): $7.8-8.4(\mathrm{Ar}-\mathrm{H}, \mathrm{m}, 18 \mathrm{H})$.

\subsection{Biological Screening}

Potato Dextrose Agar (PDA) plates were flooded with spore suspension of each fungus. About $6 \mathrm{~mm}$ diameter filter paper discs were sterilized in petri dishes at $160^{\circ} \mathrm{C}$ for 2 hours. With the aid of sterilized pair of forceps, filter paper discs that have been soaked in solutions of various concentrations of each synthesized compound were put on the surface of inoculated PDA plates. Filter paper discs were also soaked in the standard and the control and then placed on the surface of inoculated PDA plates. All the PDA plates were put in an incubator at room temperature. The growth diameter of the fungal spore was measured at every 24 hours until when there was a complete growth of fungus on the control plate. The minimum concentration of each synthesized compound that gave $100 \%$ inhibition of fungus growth was taken as the 'Minimal Inhibitory Concentration' (MIC) of the compound [2]. The $\mathrm{IC}_{50}$ (Inhibitory concentration of the synthesized compound at $50 \%$ inhibition of the fungus population) was extrapolated from the graph of percentage inhibition (\%I) of fungus against concentration of the synthesized compound $[2,24]$.

\section{RESULTS AND DISCUSSION}

The values of the minimal inhibitory concentration (MIC) and the $50 \%$ inhibitory concentration $\left(\mathrm{IC}_{50}\right)$ of the synthesized compounds are presented in Table 1.

The data obtained clearly showed that the sulphide derivatives retained the fungicidal activity exhibited by the corresponding phenyl carbamates. Not only sulphide derivatives retained the fungicidal activity of their parent carbamates, they were found to be significantly more fungicidal to all the fungi species. The inhibitory effect of O-phenyl carbamates on the fungi species has been probably enhanced by the presence of sulphur. Organic sulphur compounds could migrate into the fungus cells and take part in chemical reactions that could lead to increase in activity [5].

Sulphur derivatives of O-phenyl-N-phenyl carbamate showed greater activity towards Aspergillus species. From the results obtained in Table 1, the activity of the synthesized monosulphides and disulphides (in terms of MIC) towards Aspergillus species doubled that of other fungi species. This is an indication that Aspergillus species were more susceptible to sulphur derivatives of Ophenyl-N-phenyl carbamate than Fusarium oxysporum and Rhizopus stolonifer.

Generally, compounds with substituents at the meta position of the benzene ring showed greater activity than those with substituents at the para position. In all the synthesized compounds, activity decreased with decrease in concentration. This is in agreement with our earlier findings [2]. Increase the number of sulphur atoms did not contribute significantly to the fungicidal activity of the synthesized compounds. The monosulphides were even more active than most of their corresponding disulphides as indicated by their $\mathrm{IC}_{50}$ results (Table 1)

When compared with the results obtained in the previous paper, the sulphide derivatives of O-phenyl-Nphenyl carbamate showed greater activity than the sulphide derivatives of O-ethyl-N-phenyl carbamate [23]. The delocalization of electrons that takes place in the phenoxy groups of sulphide derivatives of O-phenyl-Nphenyl carbamate would increase the nucleophlic property of these compounds and this could lead to increase in activity [2]. 
Table 1. Inhibitory effect of the synthesized compounds on the fungi species through MIC and $\mathrm{IC}_{50}$ in ppm.

\begin{tabular}{|c|c|c|c|c|c|c|c|c|c|}
\hline \multirow{2}{*}{$\mathrm{S} / \mathrm{N}$} & \multirow{2}{*}{ Synthesized compounds } & \multicolumn{2}{|c|}{$\begin{array}{l}\text { Aspergillus } \\
\text { niger }\end{array}$} & \multicolumn{2}{|c|}{$\begin{array}{l}\text { Aspergillus } \\
\text { flavus }\end{array}$} & \multicolumn{2}{|c|}{$\begin{array}{l}\text { Rhizopus } \\
\text { stolonifer }\end{array}$} & \multicolumn{2}{|c|}{$\begin{array}{l}\text { Fusarium } \\
\text { oxysporum }\end{array}$} \\
\hline & & MIC & $\mathrm{IC}_{50}$ & MIC & $\mathrm{IC}_{50}$ & MIC & $\mathrm{IC}_{50}$ & MIC & $\mathrm{IC}_{50}$ \\
\hline 1 & O-phenyl-N-(3-nitrophenyl) carbamate & 50 & 25 & 50 & 24 & 50 & 27 & 50 & 26 \\
\hline 2 & O-phenyl-N-(4-nitrophenyl) carbamate & 100 & 45 & 100 & 48 & 100 & 55 & 100 & 52 \\
\hline 3 & O-phenyl-N-(4-chlorophenyl) carbamate & 100 & 49 & 100 & 47 & 100 & 60 & 100 & 58 \\
\hline 4 & $\begin{array}{l}\text { Bis-[N-phenoxycarbonyl-N-(3-nitrophenyl)] } \\
\text { monosulphide }\end{array}$ & 10 & 5 & 10 & 4 & 20 & 13 & 20 & 15 \\
\hline 5 & $\begin{array}{l}\text { Bis-[N-phenoxycarbonyl-N-(4-nitrophenyl)] } \\
\text { monosulphide }\end{array}$ & 25 & 13 & 25 & 15 & 50 & 26 & 50 & 26 \\
\hline 6 & $\begin{array}{l}\text { Bis-[N-phenoxycarbonyl-N-(4-chlorophenyl)] } \\
\text { monosulphide }\end{array}$ & 25 & 11 & 25 & 12 & 50 & 20 & 50 & 23 \\
\hline 7 & $\begin{array}{l}\text { Bis-[N-phenoxycarbonyl-N-(3-nitrophenyl)] } \\
\text { disulphide }\end{array}$ & 10 & 07 & 10 & 6 & 20 & 15 & 20 & 14 \\
\hline 8 & $\begin{array}{l}\text { Bis-[N-phenoxycarbonyl-N-(4-nitrophenyl)] } \\
\text { disulphide }\end{array}$ & 25 & 17 & 25 & 15 & 50 & 28 & 50 & 27 \\
\hline 9 & $\begin{array}{l}\text { Bis-[N-phenoxycarbonyl-N(4-chlorophenyl)] } \\
\text { disulphide }\end{array}$ & 25 & 12 & 25 & 12 & 50 & 23 & 50 & 24 \\
\hline 10 & Phenylmercury acetate (standard) & 5 & 1 & 5 & 1 & 5 & 2 & 5 & 2 \\
\hline 11 & DMSO/ $\mathrm{H}_{2} \mathrm{O}$ (8:2) (Control) & 0 & 0 & 0 & 0 & 0 & 0 & 0 & 0 \\
\hline
\end{tabular}

\section{CONCLUSIONS}

In the continuation of our research efforts on the syntheses and structural activity of organic sulphur compounds as potential fungicides, we have studied the fungicidal activity of sulphur derivatives of O-phenyl-N-phenyl carbamates and the results obtained showed that there was an improvement in the fungicidal activity when compared with their parent compounds and the earlier prepared sulphur derivatives of O-ethyl-N-phenyl carbamate.

\section{REFERENCES}

[1] Lamberth, C. (2004) Sulfur chemistry in crop protection. Journal of Sulfur Chemistry, 25, 39-62. doi:10.1080/17415990310001612290

[2] Adelowo-Imeokparia, F., Faboya, O.O.P. and Ojo, I.A.O., (2005) Synthesis and fungicidalactivity of some phenyl carbamates. International Journal of Chemistry, 15, 101111.

[3] Lukens, R.J. (1971) Chemistry of fungicidal action. Chapman and Hall Ltd., London, 1-138.

[4] Metcalf, R.L. (1971) Chemistry and biology of pesticides. In: White-Stevens, R., Ed., Pesticides in The Environment, R. Dekker, New York, 1.

[5] Cremlyn, R. (1979) Pesticides: Preparation and mode of action. John Wiley and Sons, Ltd., Hoboken, 114-115.

[6] Young, D.E. (1988) U.S. Patent No. 726144.

[7] Ayodele, E.T. (1994) Studies in the synthesis and fungicidal activity of some substituted benzyl-2-hydroxyethyl oligosulphide and related compounds. Ph.D thesis, Uni- versity of North London, London.

[8] Sonawane L.V. and Bari, S.B. (2011) Synthesis and spectral characterization of some novel n-substituted 2,4-Thia-zolidinedione. International Journal of Biological Chemistry, 5, 68-74.doi:10.3923/ijbc.2011.68.74

[9] Rich, S. (1960) Fungicidal chemistry in plant pathology. Academy Press Ltd., New York, 588.

[10] Eyring, H., (1966) Untangling biological reactions. Science, 154, 1609-1613.

[11] Pattan, S.R., Suresh, C., Pujari, V.D., Reddy, V.V.K., Rasal V.P. and Koti, B.C. (2005) Synthesis and antidiabetic activity of 2-amino5'(4-sulphonylbenzylidine)-2,4-thiazolidinedione]-7-chloro-6-fluoro-benzothiazole. Indian Journal of Chemistry, 44, 2404-2408.

[12] Grogan, C.H.; Rice, L.M. and Reid, E.E. (1955) Dithiols and derivatives. Journal of Organic Chemistry, 20, 5058. doi:10.1021/jo01119a009

[13] Field, L., Owen, T.C., Crenshaw, R.R. and Bryan, A.W. (1961) Organic disulfides and related substances. IV. Thiolsulfonates and disulfides containing 2-aminoethyl moieties. Journal of the American Chemical Society, 83, 44144417. doi:10.1021/ja01482a027

[14] Szczepanski, C.V., Heindl, J.; Hoyer, G.A. and Schroder, E. (1977) Biologically active substances in plants. II: Synthesis and antimicrobial activity of some unsymmetrical oligosulphides. European Journal of Medicinal Chemistry: Chimica TherapeuticaI, 12, 279-284.

[15] Fahmy, M.A.H. and Fukuto, T.R. (1981) N-sulfinylated de- rivatives of methylcarbamate esters. Journal of Agricultural and Food Chemistry, 29, 567-572. doi:10.1021/jf00105a034

[16] Ayodele, E.T.; Hudson, H.R., Ojo, I.A.O. and Pianka, M. (2000) Organosulfur compounds aspotential fungicides: 
The preparation and properties of some substituted benzyl 2-hydroxylethyl oligosulfides. Journal of Phosphorus, Sulfur and Silicon, 159, 123-142. doi:10.1080/10426500008043656

[17] Mori, M., Takagi, M., Noritake, C. and Kagabu, S. (2008) 2, 4-Dioxo-1,3-thiazolidine derivatives as a lead for new fungicide. Journal of Pesticide Science, 33, 357-363. doi:10.1584/jpestics.G08-15

[18] Vedavathi, M., Somashekar, B, Sreenivasa, G.M. and Jayachandran, E. (2010) Synthesis, characterization and anti-microbial activity of fluoro benzothiazole incorporated with 1,3,4-Thiadiazole. Journal of Pharmaceutical Sciences and Research, 2, 53-63.

[19] Reid, E.E. (1960) Organic chemistry of bivalent sulphur. Chemical Publishing Co. Inc., New York, III, 363-367.
[20] Kharasch, N. (1961) Organic sulphur compounds. Pergamon Press, Oxford, 30-51.

[21] Kuhle, E. (1970) One hundred years of sulfenic acid chemistry, sulfenyl halide synthesis. Synthesis, 11, 560580.

[22] Ayodele, E.T. (2005) Preparation and glass house screening of some substituted benzyl-2-hydroxylethyl oligosulfides. Science Focus, 10, 56-62.

[23] Adelowo-Imeokparia, F. and Ojo, I.A.O. (2006) Synthesis and fungicidal activity of some sulphide derivatives of O-ethyl-N-substituted phenylcarbamates. Pakistan Journal of Scientific and Industrial Research, 49, 324-329.

[24] Tabakova, S. and Dodoff, N. (1995) Effect of platinum (II) complexes of benzoic and 3-methoxybenzoic acid hydrazides on Saccharomyces serevisiae. Zeitschrift für Naturforschung, 50c, 732-743. 